\title{
The Influence of Internal Control Organizations and Self Control of Employee Cheating (An Experimental Study)
}

\author{
A.A..Bagus. Amlayasa ${ }^{1}$, Ni Made Taman $\mathrm{Sari}^{2}$, I G. A. Intan Saputera Rini ${ }^{3}$ \\ amlayasaabgs@gmail.com ${ }^{1}$
}

Faculty Ekonomi Universitas Warmadewa Denpasar-Bali, Indonesia ${ }^{123}$

\begin{abstract}
This study examines the effect of organizational internal control and self-control on employee fraud. The type of data used is qualitative data. Sources of data are sourced from primary data using a laboratory experiment design with participants of 58 post-graduate students from the Faculty of Economics and Business, University of Brawijaya Malang. Data testing conducted in this study to test the research hypotheses, which includes frequency distribution for descriptive statistics, homogeneity test, and normality test data. After that, analysis of variance (ANOVA) was carried out and independent statistical tests $t$ test using SPSS Version 16. The results of this study prove that there are differences in the tendency of employees to commit fraud between employees with high self-control and low self-control. Employees with higher self-control tend not to cheat compared to employees with lower self-control. There are differences in the tendency of employees to commit fraud between organizations and internal control systems compared to no internal control system. Organizations with internal control systems tend not to occur cheating compared to organizations without internal control systems.
\end{abstract}

Keywords: Organizational Internal Control, Self Control, Employee Fraud

\section{Introduction}

Financial statements as part of accounting information can be useful for all parties if they have high relevance and reliability based on transparent and accountable principles. However, with the many interests of various internal stakeholders, especially employees and management, these financial statements are prone to the emergence of fraud such as corruption, asset abuse and financial report manipulation [1].

The 2017 Corruption Perceptions Index data shows that Indonesia is ranked 107 out of 175 countries with a score of 34 . The ranking and score indicate an increase in efforts to eradicate corruption in the country. However, Indonesia's ranking is still below the average GPA of countries in the ASEAN region. In ASEAN, Indonesia still loses compared to Malaysia with a score (52), Singapore with a score (98), Thailand with a score (38), and the Philippines with a score (36). This means that eradicating corruption in Indonesia is still low and requires systematic efforts by the government and assisted by all professions in the community.

Wright proves that internal bureaucracy has an influence on government accounting fraud [2]. These findings are in line with those carried out by Sanusi et al. with experimental design. There is evidence that internal control (SPI) has an impact on fraud risk assessment. This shows that the better the company's internal control, the lower the fraud rate accounting. [3]

Fauwzi, provides empirical evidence that internal control and management morality have a significant negative effect on unethical behavior and accounting fraud tendencies, while compensation suitability has no effect on unethical behavior and has a positive effect on accounting trends. [4] Haron et.al. with an experimental design that proved that personality effects were not proven to be moderating in the relationship of risk assessment of fraud with fraud detection. [5]

Based on the inconsistency of the results of previous studies, this study aims to obtain empirical evidence of the effect of internal control and self-control on employee fraud. Internal control variables use two levels of treatment namely internal control and no internal control. The self-control variable uses two levels of treatment namely low self-control and high self-control. The Research Concept Framework in this study can be shown in the following figure: 


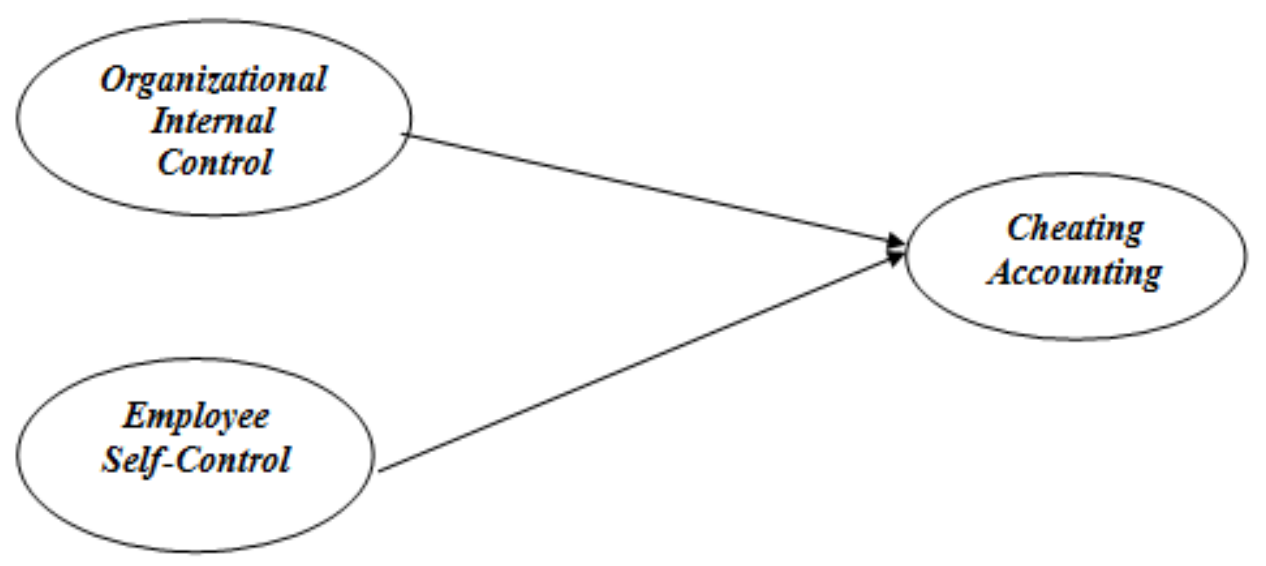

Fig. 1. Research Concept Framework

\section{Reseach Methods}

This study uses the experimental method approach. The use of pure experiments because in this study uses randomization and data sources obtained from the manipulation of one or more independent variables. [6]

The experimental participants in this study were 58 students of the Accounting Science Doctoral Program in the Postgraduate Program of Brawijaya University Malang. The consideration of researchers using management master students is:

1. The laboratory experiment process is a fairly long process, so the possibility of involving real employees will be very difficult.

2. Most management master students are already working so that it can be said to be closer to the real thing.

Experimental design in this study used pure experiments with factorial $2 \mathrm{X} 2$ between subject and within subject designs. Factorial design is an experimental design that simultaneously accommodates research on the influence of two or more independent variables [6].

\subsection{Experimental Procedure}

Before the actual experiment is carried out, the Pilot Test activity is carried out first, which serves as an early warning about where the possibility of the study fails and allows for the necessary improvements. The Pilot Test also aims to find out whether the given case can be understood by participants or not. This activity was carried out and given to seventh semester students in the accounting department of the Reg B class, Faculty of Economics, Warmadewa University. The results of the manipulation check prove that participants can understand the contents of the questionnaire where all answers to the questionnaire can be filled in completely.

\section{Result and Discussion}

The results of the normality test data indicate that the value of Asymp. Sig. (2-tailed) obtained a value of 0.007 (below 0.05 ) indicating data is not normally distributed. Although the normality test is not fulfilled, however, the ANOVA test is still Robust (Ghozali, 2013) and the homogeneity test results show that the Levene's Test value is 0.779 (above 0.05). [7] 
The following table presents the results of descriptive statistics for the four treatment groups as follows:

Table 1. Deskriptif Statistik

\begin{tabular}{lccccc}
\hline \multirow{2}{*}{ S C } & SPI & & Std. & \\
\hline Low & & No SPI (Grup 3) & 1.3425 & .73167 & 17 \\
& & SPI (Grup 1) & 1.1368 & .64478 & 14 \\
& Total & & 1.2496 & .69029 & 31 \\
High & & No SPI (Grup 4) & 1.2114 & .73083 & 13 \\
& & SPI (Grup 2) & .4494 & .77059 & 14 \\
& Total & & .8163 & .83305 & 27 \\
Total & None & & 1.2857 & .72162 & 30 \\
& SPI & & .7931 & .78012 & 28 \\
& Total & & 1.0479 & .78414 & 58 \\
\hline
\end{tabular}

Table 1 shows that participants in group 3 numbered 17 people, with the treatment there was no element of internal control and the low level of self-control had the highest mean of 1.3425. Group 1 with treatment there is an element of internal control and a low level of self-control has a mean of 1.1368 with the number of participants being 13 people. Participants who have a high level of selfcontrol, namely group 4 and group 2 have their respective mean of 1,12114 and 0,4494 with different treatments, namely there are elements of internal control and no internal control elements.

Next for the Hypothesis Test, Two-Way Analysis of Variance (ANOVA) is used as shown in the following table 2 :

Tabel 2. Tests of Between-Subjects Effects

\begin{tabular}{|c|c|c|c|c|c|}
\hline Source & $\begin{array}{l}\text { Type I Sum of } \\
\text { Squares }\end{array}$ & Df & $\begin{array}{l}\text { Mean } \\
\text { Square }\end{array}$ & $\mathrm{F}$ & Sig. \\
\hline Corrected Mode & $6.949^{\mathrm{a}}$ & 3 & 2.316 & 4.451 & .007 \\
\hline Intercept & 61.525 & 1 & 61.525 & 118.238 & .000 \\
\hline $\mathrm{SC} * \mathrm{SPI}$ & 1.111 & 1 & 1.111 & 2.135 & .150 \\
\hline $\mathrm{SC}$ & 2.405 & 1 & 2.405 & 4.621 & .036 \\
\hline SPI & 3.362 & 1 & 3.362 & 6.460 & .014 \\
\hline
\end{tabular}


The results of the analysis in Table 2 show that the Sig coefficient values for hypotheses 1 and 2 (the hypothesis of the effect of self control, the effect of internal control) are all smaller than the specified alpha $(5 \%)$. Thus it can be concluded that all hypotheses are supported ( $\mathrm{H} 1$ and $\mathrm{H} 2)$.

Supporting H1 can be stated that there are differences in the tendency of accounting fraud between employees in the condition that there are elements of internal control and there are no elements of internal control. The results of this study at the same time strengthen the results of previous studies conducted by Holmes et al. (2002) [8] and Moffett et.al (2011) [9]

Supporting $\mathrm{H} 2$ can be stated that there are differences in the tendency of accounting fraud between individuals who have a high level of self control and a low level of self control and it can also be concluded that $\mathrm{H} 2$ is supported because there are differences in the tendency to commit accounting fraud caused by individual self-control without regard to other treatments.

The results of this study at the same time strengthen the results of ethical studies previously conducted by Chaplin (2005) [10], Wilopo (2006) [11], Bernardi and Guptill (2008) [12] Moroney and McDevitt (2008) [13], Liyanarachi (2009) [14], Barra (2010) [15] and Engel (2012) and Sulistyo (2011 [16].

\section{Conclusion}

Based on the formulation of the problem, research objectives, theoretical basis, hypothesis and research results, the conclusion of this study is that there are differences in the tendency of individuals to commit accounting fraud between individuals in the organization there are SPI element conditions and no SPI and there are differences in the tendency of individuals to commit accounting fraud between individuals who have high levels of selfcontrol and individuals who have low levels of self-control. The findings of this study are important for the education of the accounting profession. The results of this study found the need to sharpen the material of professional ethics education with emphasis on aspects of individual morality.

This study has limitations, this research uses students as surrogates of real employees, so the generalization aspect is low. This study also uses cases with existing or no SPI conditions. Whereas in actual practice SPI can be simpler or complex. Subsequent research can be expanded by using actual employees as participants in the experiment. In addition, other variables can also be included in the research model, namely aspects of gender, education level, income level and other demographic aspects.

\section{References}

[1] Association of Certified Kecurangan Examinations (ACFE), "ACFE Reports The Nations 2014," 2014.

[2] P. M. Wright, "Restoring Trust: The Role of HR in Corporate Governance. September, 2003. www.ilr.cornell.edu/cahrs," 2003.

[3] and M.-D. M.-N. Sanusi Zuraidah Mohdi, Norhayati Mohamed, Normah Omar, "Effects of Internal Controls, Kecurangan Motives and Experience in Assessing Likelihood of Kecurangan Risk,” J. Econ. Bus. Manag., vol. 3, no. 2, 2015.

[4] Fauwzi, "Analisis Pengaruh Keefektifan Pengendalian Internal, Persepsi Kesesuaian Kompensasi, Moralitas Manajemen Terhadap Perilaku Tidak Etis dan Kecenderungan Kecurangan Akuntansi.," J. Akunt. Univ. Diponegoro Semarang, 2011.

[5] A. S. Haron Hasnah, Nahariah Jaffar, "Kecurangan Risk Assessment and Detection of Kecurangan: 
The Moderating Effect of Personality,” Int. J. Bus. Manag., vol. 6, no. 7, 2011.

[6] E. Nahartyo, "Desain dan Implementasi Riset Eksperimen," UUP STIM YKPN Yogyakarta, 2013.

[7] I. Ghozali, Aplikasi Analisis Multivariat dengan Program IBM SPSS 21, 7th ed. Semarang: Penerbit Universitas Diponegoro, 2013.

[8] O. J. W. dan S. T. W. Holmes Sarah A., Margaret Langford, "Associations Between Internal Controls And Organizational Citizenship Behavior,” J. Manag. Issues, vol. XIV, no. 1, pp. 5-99, 2002.

[9] G. H. Moffett, Ryan C; Grant, "Internal Controls And Fraud Prevention. Internal Auditing; Mar/Apr 2011; 26, 2; ABI/INFORM Complete,” pp. 3-11, 2011.

[10] J. P. Chaplin, Kamus Lengkap Psikologi. Jakarta: Rajawali Pers, 2005.

[11] Wilopo, "Analisis Faktor-Faktor yang Berpengaruh Terhadap Kecenderungan Kecurangan Akuntansi : Studi pada Perusahaan Publik dan Badan Usaha Milik Negara (BUMN) di Indonesia," J. Ris. Akunt. Indones., vol. 9, 2006.

[12] R. and S. G. Bernardi, "Social Desirability Response Bias, Gender and Factors Influencing Organizational Commitment: An International Study,” J. Bus. Ethics, 2008.

[13] J. J. and R. E. M. Moroney, "The Effects of Moral Reasoning on Financial Reporting Decisions in a Post Sarbanes-Oxley Environment," Behav. Res. Account., 2008.

[14] G. Liyanarachi, "The Impact of Moral Reasoning and Retaliation on Whistle- Blowing: NewZealand Evidence,” J. Bus. Ethics, vol. 89, 2009.

[15] R. A. Barra, "The Impact of Internal Controls and Penalties on Kecurangan," J. Inf. Syst. Am. Account. Assoc., vol. 24, no. 1, pp. 1-21, 2010. 